\title{
Food and macronutrient intake of male adolescent Kalenjin runners in Kenya
}

\author{
Dirk L. Christensen ${ }^{1} *$, Gerrit van Hall $^{2}$ and Leif Hambraeus ${ }^{3}$ \\ ${ }^{1}$ Centre of African Studies, University of Copenhagen, Copenhagen, Denmark \\ ${ }^{2}$ Copenhagen Muscle Research Centre, Rigshospitalet (University Hospital), Copenhagen, Denmark \\ ${ }^{3}$ Department of Medical Sciences, Nutrition Unit, Uppsala University, Uppsala, Sweden
}

(Received 13 December 2001 - Revised 8 July 2002 - Accepted 15 August 2002)

\begin{abstract}
A nutritional survey based on twelve adolescent male Kalenjin runners in Kenya during a 2week field study was carried out in order to determine the composition of their diet and make a comparison with macronutrient recommendations for athletes. Food samples were collected for analysis of macronutrient distribution and energy content from main meals and the macronutrient distribution and energy content of additional food intake were based on the information of a $24 \mathrm{~h}$ recall interview and estimated from food tables. The diet of the Kalenjin runners was very high in carbohydrate $(71 \% 8.7 \mathrm{~g} / \mathrm{kg}$ body weight per d) and very low in fat $(15 \%)$. Intake of total protein $(13 \% ; 1.6 \mathrm{~g} / \mathrm{kg}$ body weight per d) was above the daily intake recommended by the Food and Agriculture Organization/World Health Organization/United Nations University (FAO/WHO/UNU), while essential amino acid intake was estimated to be in the borderline-to-low range based on $\mathrm{FAO} / \mathrm{WHO} / \mathrm{UNU}$ recommendations for children $<12$ years and adults. The energy intake was mainly derived from vegetable sources $(90 \%)$ with maize and kidney beans as the staple food $(81 \%)$. The diet of the Kalenjin runners met recommendations for endurance athletes for total protein and most essential amino acid intake as well as carbohydrate intake even though it was based on a small range of food items.
\end{abstract}

Diet: Carbohydrate: Fat: Protein: Essential amino acids: Runners

The Kenyan success in middle- and long-distance running, especially among male athletes, has been one of the most astonishing features of international athletics since the mid-1960s. Training and competing at the elite level in the middle and long distances requires an optimal functioning of the body, which relies on a nutritionally adequate diet providing sufficient energy as well as an adequate content of macronutrients. The literature provides much evidence of the advantage of a high carbohydrate intake ranging from $60 \%$ to more than $70 \%$ (Sherman, 1983; Costill, 1985; Devlin \& Williams, 1991). However, there is disagreement concerning the amount of protein intake necessary for an endurance athlete. Several studies (Henderson et al. 1985; Friedman \& Lemon, 1989; Meridith et al. 1989) but not all (Hood \& Terjung, 1987) using amino acid oxidation, $\mathrm{N}$ balance or metabolic tracer methodology indicate an enhanced protein need greater than the $0.8 \mathrm{~g} / \mathrm{kg}$ body weight per $\mathrm{d}$ recommended by the Food and Agriculture Organization/World Health Organization/ United Nations University (1985).
Several diet studies have been carried out in Kenya over the past 75 years, but except for one they have all dealt with non-athletic dietary intake such as diet and health in the general population (Wadsworth, 1960; Korte \& Simmons, 1972; Kulin et al. 1982). Malnutrition among Kenyan children was significant (Government of Kenya, 1980), and has recently been verified by Ngare \& Muttunga (1999).

Diet has not been comprehensively studied in connection with Kenyan runners. Only Mukeshi \& Thairu (1993) have included elite Kenyan long-distance runners in a diet study. They evaluated food intake $2 \mathrm{~d}$ per month over a 3-month period based on questionnaires. The results may not be representative of a 'usual' diet intake as the authors claim. This is indicated by the fact that daily energy intake was measured to be only $9790 \mathrm{~kJ}$ for male runners, which hardly leaves any room for endurance training at the elite level.

An interesting aspect of Kenyan middle- and longdistance running is that most of the talent originates from 
the western part of Kenya in the Great Rift Valley area (Naibei, 1989). More specifically, successful athletes have emerged from eight ethnic sub-groups of Nilotic descent called Kipsigis, Nandi, Terik, Marakwet, Keiyo, Tugen, Sabaot and Pokot, respectively, regarded as one ethnic group called Kalenjin (Kipkorir, 1985).

The purpose of the present study was to investigate the dietary intake of male adolescent Kalenjin middle- and long-distance runners and make a comparison with macronutrient recommendations for endurance athletes. The study included the collection and analysis of food samples representative of the diet of the Kalenjin runners, which cannot be found in completeness in food tables. Furthermore, the present study estimated the energy expenditure of the adolescent runners based on their training and physical activity in general, and special care was taken to thoroughly estimate energy intake by also including $24 \mathrm{~h}$ recall interviews.

\section{Methods \\ Subjects}

Twelve representative athletes were chosen by lot as subjects for the present study, all of them Kalenjins. As for the Kalenjin sub-groups, eight were Marakwet, three were Keiyo and one was Sabaot. All subjects were students at Marakwet Secondary School and all were competitive middle- and long-distance runners on the school's athletics team, which at the time of the study consisted of twentyfive athletes, all of them runners. As a group they were regarded as some of the best runners at regional level based on their personal-best performances from the $800 \mathrm{~m}$ to $8 \mathrm{~km}$ cross-country. Marakwet Secondary School is a boarding school situated approximately $2600 \mathrm{~m}$ above sea level in the Marakwet district (Cappon, 1985). Furthermore, all subjects spoke Kiswahili and dialects of Kalenjin as well as some English. A local Kenyan interpreted the necessary information in case of insufficiency in English by the subjects.
The subjects had an average age of $17 \cdot 1$ (range 15-20) years. Their anthropometric data are presented in Table 1.

\section{Protocol}

The dietary intake of the subjects was measured daily for 2 weeks in the month of May during the rainy season. Later visits by one of the authors to Marakwet Secondary School showed that 2 weeks of food measurement was representative of the student-athletes' meal pattern. Food items from every meal including breakfast, morning coffee, lunch and dinner were collected for analysis. In addition, $24 \mathrm{~h}$ recall interviews were carried out every morning according to the method used by Wiehl (1942) to account for food consumed between meals and to check the reliability of the information given by the subjects from the $24 \mathrm{~h}$ recall interviews. The estimated dietary intake according to the $24 \mathrm{~h}$ recall interviews was consistent with the actual measurements of the food intake. This is in agreement with other studies carried out on subjects who consumed a limited number of food items and have a standard meal pattern like the Kalenjin (Cerqueira et al. 1979; van Steenbergen et al. 1984).

The $24 \mathrm{~h}$ recall interviews were also carried out in order to estimate the daily physical activity level (PAL) of the Kalenjin runners. In this respect the runners were asked to specify daily quantity as well as quality of running, stretching exercises, strength training as well as additional sports, i.e. ball games performed outside the daily training schedule. Furthermore, they were asked to estimate the amount of time spent sitting and standing. Time spent resting was calculated by subtracting the hours spent on activities including sitting and standing from $24 \mathrm{~h}$.

The meal composition of the athletes was in general not different from that of the other students at Marakwet Secondary School. However, the subjects did purchase a small amount of extra food at their own expense on an irregular basis, i.e. bread, milk, oranges and soft drinks, which was included in the estimation of their diet intake. Furthermore, members of the athletics team did not receive any specific dietary recommendations from their coach.

Table 1. Height, weight, weight change and body mass index of subjects during 2 weeks of training

(Measured values and mean values with their standard errors)

\begin{tabular}{|c|c|c|c|c|c|}
\hline Subject no. & Height & Start weight & End weight & Weight change & $\mathrm{BMI}^{*}$ \\
\hline 1 & 173 & $55 \cdot 0$ & 54.5 & -0.5 & $18 \cdot 3$ \\
\hline 2 & 170 & $54 \cdot 0$ & $54 \cdot 0$ & 0.0 & $18 \cdot 7$ \\
\hline 3 & 171 & $55 \cdot 0$ & $55 \cdot 0$ & 0.0 & $18 \cdot 8$ \\
\hline 4 & 174 & $60 \cdot 0$ & $61 \cdot 0$ & $+1 \cdot 0$ & $20 \cdot 0$ \\
\hline 5 & 173 & $55 \cdot 0$ & $56 \cdot 5$ & +1.5 & $18 \cdot 6$ \\
\hline 6 & 166 & $50 \cdot 0$ & $50 \cdot 0$ & 0.0 & $18 \cdot 1$ \\
\hline 7 & 169 & $54 \cdot 0$ & $53 \cdot 0$ & -1.0 & $18 \cdot 7$ \\
\hline 8 & 160 & $45 \cdot 0$ & $45 \cdot 0$ & 0.0 & $17 \cdot 6$ \\
\hline 9 & 180 & 64.0 & 64.5 & +0.5 & $19 \cdot 8$ \\
\hline 10 & 179 & $65 \cdot 0$ & $66 \cdot 0$ & $+1 \cdot 0$ & $20 \cdot 4$ \\
\hline 11 & 177 & $56 \cdot 0$ & $57 \cdot 0$ & $+1 \cdot 0$ & $18 \cdot 0$ \\
\hline 12 & 158 & $46 \cdot 5$ & $48 \cdot 0$ & $+1 \cdot 5$ & $18 \cdot 9$ \\
\hline Mean & 170 & $55 \cdot 0$ & $55 \cdot 4$ & +0.7 & $18 \cdot 8$ \\
\hline SE & $2 \cdot 0$ & $1 \cdot 8$ & $1 \cdot 8$ & 0.2 & 0.2 \\
\hline
\end{tabular}

* Based on the average of start and end weight. 
The meal and training routines of the subjects at Marakwet Secondary School all followed a daily standard schedule. Meals were served at 6.30 hours (breakfast), 11.00 hours (morning coffee), 12.45 hours (lunch) and 18.15 hours (dinner). Organized training was done twice a day, before breakfast (distance run of $6 \mathrm{~km}$ ) and before dinner (distance run or interval training of $4.0 \mathrm{~km}$ ), including gymnastic exercises and stretching following both training sessions. Immediately after finishing classes the subjects would be engaged in different ball games.

Dietary calculations of nutrient intake for each individual were based on analysis after weighing all meals of the subjects within $1 \mathrm{~g}$ of accuracy on an Ohaus LS-2000 Portable Standard (Ohaus Corp., Pine Brook, NJ, USA).

\section{Food analysis}

All foods were analysed at Uppsala University, Sweden except for meat, oranges and soft drinks. Dietary calculations of the latter three items were based on food composition tables (West et al. 1988). Analysis of cabbage and kale was done on raw samples and not from the prepared form in which they were consumed. The physical combustion value of all foods was measured in a Parr bomb calorimeter (Parr Instrument Company, Moline, IL, USA) for energy. The percentage energy distribution of the macronutrients was derived from the Atwater energy factors (Merrill \& Watt, 1973). Total protein was calculated from analysis of $\mathrm{N}$ by the Kjeldahl titration method (Kjeltec Auto 1030 Analyzer; Foss Tecator, Foss North America, Inc., Eden Prairie, MN, USA), the $\mathrm{N}$ factor being 6.25 for all samples except for milk, which was calculated based on an $\mathrm{N}$ factor of 6.38 (Jones, 1941). Fat was measured by petroleumeter extraction according to the Soxhlet method, and carbohydrate was calculated 'by difference', i.e. a sample extracting water, protein, fat and ash. Essential amino acids were measured after hydrolysis in $\mathrm{HCl}$ using an automatic amino acid analyser (LKB 4151 Alpha Plus Amino Acid Analyzer; Pharmacia - LKB Biochrom Ltd, Cambridge, UK). All analyses were carried out in duplicate. All values presented in the text are given as mean and SE unless otherwise stated.

\section{Results}

Based on $24 \mathrm{~h}$ recall interviews the subjects ran an average of $10 \mathrm{~km} / \mathrm{d}$. Other physical activities throughout the day, for example, ball games, strength training, gymnastics, stretching, amounted to $21 \%$ of PAL, derived according to the recommended daily allowance (RDA) (physical activity factor/physical activity rate) of the Nordic countries (Sandström et al. 1996). In total, this resulted in a PAL of 2.0 (SE 0.1) (Table 2).

The mean energy expenditure using another definition of PAL (total energy expenditure/BMR) (Black et al. 1996) should then be 13186 (SE 274) kJ/d (range 11551$14944 \mathrm{~kJ} / \mathrm{d}$ ), which could be compared with the daily total energy intake of the subjects based on the assessment of dietary intake, 13210 (SE 283) kJ/d (range 11860$14648 \mathrm{~kJ} / \mathrm{d}$ ). The calculated delta value (energy intake/ energy expenditure) turned out to be 1.0 (SD 0.1) (range $0 \cdot 79-1 \cdot 21)$.

The staple foods of the Kalenjin runners were maize and kidney beans, both being served every day. They were consumed as ugali (a thick maize porridge), uji (a thin, fermented maize porridge) and githeri (maize and kidney beans cooked together). Other foods and drinks being consumed on a daily basis were cabbage and curly kale (both cooked), coffee (with milk) and milk (fermented).

The subjects consumed 11763 (SE 302) kJ/d (range $9857-13387 \mathrm{~kJ} / \mathrm{d}$ ) based on vegetable sources, being a total of 90 (SE 0.6$) \%$ of the energy intake. The staple foods maize and kidney beans alone made up 81 (SE 0.7) $\%$ of the total energy intake or 10833 (SE 303) kJ/d (range $8922-12451 \mathrm{~kJ} / \mathrm{d}$ ). As for the different values of the macronutrients, carbohydrate intake was 476 (SE 11.7) g, of which 462 (SE 11.4) g (97\%) came from vegetable sources and 445 (SE 11.7) g (93\%) from maize and kidney beans. The total intake of fat was 45.2 (SE 1.0) $\mathrm{g}$ with 29.8 (SE 0.8) g (65\%) derived from vegetable foods, of which 26.9 (SE 0.8$) \mathrm{g}(60 \%)$ came from maize and kidney beans. Total protein intake was 88 (SE 1.8) g comprising 75 (SE 2.0) g (85\%) from vegetable sources and 64 (SE 2.0) g $(74 \%)$ from maize and kidney beans, as meat (beef) was served only twice a week totalling 177 (SE 17.2)

Table 2. Estimated physical activity level per day for twelve runners based on $24 \mathrm{~h}$ recall interviews

(Mean values with their standard errors)

\begin{tabular}{|c|c|c|c|c|c|}
\hline & \multirow[b]{2}{*}{ Physical activity rate* } & \multicolumn{2}{|c|}{ Duration (h) } & \multicolumn{2}{|c|}{$\begin{array}{l}\text { Physical } \\
\text { activity factor }\end{array}$} \\
\hline & & Mean & SE & Mean & SE \\
\hline Rest & $1 \cdot 0$ & $9 \cdot 0$ & 0.0 & $9 \cdot 0$ & 0.0 \\
\hline Very low activity rate† & 1.5 & $8 \cdot 0$ & 0.0 & $12 \cdot 0$ & 0.0 \\
\hline Low activity rateł & 2.5 & $4 \cdot 0$ & 0.0 & $10 \cdot 0$ & 0.0 \\
\hline Moderate activity rate§ & $5 \cdot 0$ & $2 \cdot 0$ & 0.1 & $10 \cdot 0$ & 0.1 \\
\hline Heavy activity rate\|l & $7 \cdot 0$ & $1 \cdot 0$ & 0.1 & $7 \cdot 0$ & 0.1 \\
\hline Total rate (mean and SE) & & $24 \cdot 0$ & $0 \cdot 1$ & $48 \cdot 0$ & 0.1 \\
\hline
\end{tabular}

* Energy expenditure expressed in relationship to BMR (i.e. BMR $\times 1 \cdot 0$ ).

† Sitting, standing.

$\ddagger$ Walking, stretching after running.

$\S$ Ball games, gymnastic exercises, strength training.

\| Running. 
$\mathrm{g} /$ week. The distribution of major food sources expressed as a percentage of daily energy intake is presented in Table 3.

The percentage energy distribution of the macronutrients was 71 (SE 0.5) for carbohydrate, 15 (SE 0.3) for fat and 13 (SE 0.1) for protein. The daily carbohydrate intake was 8.7 (SE 0.4$) \mathrm{g} / \mathrm{kg}$ body weight. For protein the daily intake was $1.6($ SE 0.1$) \mathrm{g} / \mathrm{kg}$ body weight.

The essential amino acid intake was $25.2 \mathrm{~g} / \mathrm{d}$ or $29 \%$ of total daily protein intake. Essential amino acid intake of the subjects met the requirements for adults made by the Food and Agriculture Organization/World Health Organization/ United Nations University (1985) except for isoleucine and histidine. Whether methionine+cystine and tryptophan intake met the requirements could not be determined, as cystine and tryptophan were not analysed. The RDA of the Food and Agriculture Organization/World Health Authority/United Nations University (1985) for essential amino acids for adults are presented in Table 4.

Mean daily dietary fibre was 45.1 (SE 1.0) g (range $37.9-50.2 \mathrm{~g}$ ) or $2.9(\mathrm{SD} 0 \cdot 2) \mathrm{g} / \mathrm{MJ}$ (range $2 \cdot 6-3.3 \mathrm{~g} / \mathrm{MJ}$ ) as estimated from food tables (West et al. 1988).

\section{Discussion}

The intake of total protein was well above the RDA of the Food and Agriculture Organization/World Health Organization/United Nations University (1985), and the intake of most essential amino acids also met the RDA of the Food and Agriculture Organization/World Health Organization/United Nations University (1985) for adults. Two factors are important when considering the intake of total protein and essential amino acids: (a) the maize in Kenya is a hybrid as it has been 'mixed' with a maize from Ecuador in order to enhance the protein content (S Kimobwa, personal communication); (b) the kidney beans are high in protein and essential amino acid content.

The question of dietary protein needs of endurance athletes has been extensively studied over the past three decades. It has been known for many years that a low daily energy intake requires an elevated protein intake (Munro, 1951; Walberg et al. 1988). The Kalenjin subjects did, however, get an adequate amount of energy, which is indicated by the fact that their body weight on average only changed slightly over the 2 -week period during which the present study took place. The validity of this balance is indicated by the calculated mean energy turnover based on the physical activity records of the subjects using relevant PAL-factors and the actual assessment of their dietary intake. However, there were discrepancies at the individual level showing that some of the subjects either under- or overestimated their daily physical activities and thus their energy expenditure. Wolfe et al. (1984) showed that there was no effect from aerobic exercise on protein metabolism as total $\mathrm{N}$ excretion, urea excretion and isotopically determined urea production were not stimulated by aerobic activity, which indicates a lack of increased amino acid oxidation during or after exercise. This finding has recently been verified in $24 \mathrm{~h}$ balance studies under rigorous control of energy balance by Forslund et al. (1999), who showed that an increased 
Table 4. Relative essential amino acid intake of twelve runners

(Mean values with their standard errors)

\begin{tabular}{|c|c|c|c|c|c|}
\hline \multirow[b]{2}{*}{ Amino acid } & \multicolumn{2}{|c|}{ Total intake $(\mathrm{g} / \mathrm{d})$} & \multirow{2}{*}{$\begin{array}{c}\text { Mean relative intake } \\
(\mathrm{g} / \mathrm{kg} \text { per } \mathrm{d})\end{array}$} & \multirow[b]{2}{*}{$\% \mathrm{FAO}^{*}$} & \multirow{2}{*}{$\begin{array}{l}\text { Recommended intake } \\
(\mathrm{g} / \mathrm{kg} \text { per } \mathrm{d})\end{array}$} \\
\hline & Mean & SE & & & \\
\hline Threonine & 4.7 & 0.2 & 0.08 & 114 & 0.07 \\
\hline Valine & $6 \cdot 0$ & 0.2 & 0.11 & 110 & $0 \cdot 10$ \\
\hline Methionine+cystine & $2 \cdot 0 \dagger$ & $0 \cdot 1$ & $0.04 \dagger$ & $31 \dagger$ & 0.13 \\
\hline Isoleucine & $5 \cdot 1$ & 0.2 & 0.09 & 90 & 0.10 \\
\hline Leucine & $9 \cdot 6$ & 0.3 & 0.17 & 121 & 0.14 \\
\hline Phenylalanine+tyrosine & 9.5 & 0.3 & 0.17 & 121 & 0.14 \\
\hline Lysine & $6 \cdot 6$ & 0.3 & 0.12 & 100 & 0.12 \\
\hline Tryptophan & - & & - & & 0.04 \\
\hline Histidine & 3.4 & 0.1 & 0.06 & $50-75$ & $0.08-0.12$ \\
\hline
\end{tabular}

*Based on recommendations for adults (Food and Agriculture Organization/World Health Organization/United Nations University, 1985). † Only methionine was analysed.

energy turnover after aerobic exercise was not due to either increased rates of urea production and/or protein synthesis. Other studies have indicated that urea and total $\mathrm{N}$ excretion did increase during and after exercise (Calles-Escandon et al. 1984; Lemon et al. 1997). However, they were only performed during shorter time periods and not under strict energy balance control. The total protein intake of $1.6 \mathrm{~g} / \mathrm{kg}$ per $\mathrm{d}$ of the Kalenjin runners was higher than the amount suggested by studies that investigated the effect of aerobic training on protein oxidation and protein requirements (Gontzea et al. 1974; Tarnopolsky et al. 1988; Friedman \& Lemon, 1989; Meridith et al. 1989). This indicates that the total protein intake of the Kalenjin runners was more than sufficient to cover their needs.

Very few studies have been done on essential amino acid intake of healthy adolescents (for example, Cerqueira et al. 1979; Motil et al. 1981), and the Food and Agriculture Organization/World Health Organization/United Nations University (1985) essential amino acid requirements only present an estimate for different age groups of children up to 12 years of age as well as adults. As the subjects of the present study were in the age range of 15-20 years, they can hardly be expected to have the same need for essential amino acids as younger children, who grow at a faster rate (Sinclair, 1985). It is therefore more appropriate to make a comparison with the adult requirements even though the adolescent subjects of the present investigation had higher needs as they were still growing. The present study group is therefore thought to have a borderline-to-low essential amino acid intake.

The very low fat intake of the Kalenjin subjects could compromise intramuscular triacyglycerol storage (Kiens et al. 1987), which may affect running performances among long-distance runners as muscular triacylglycerol lipolysis has been shown to be stimulated only at higher exercise intensities (Romijn et al. 1993). However, since the subjects of the present study covered only $10 \mathrm{~km}$ of running at high intensity/d, intramuscular triacylglycerol stores do not seem to play an important role in the performance of this group. For fat intake as such, it is still unresolved whether or not there is a minimum metabolic requirement of dietary fat, beyond the requirements of essential fatty acids and fat-soluble vitamins, the effects on energy density and an adequate total energy intake (Koletzko, 1999).

The carbohydrate intake of the Kalenjin runners was $71 \%$ above the recommended 60 to more than $70 \%$ of total energy intake necessary for optimal glycogen replenishment and performance (Sherman, 1983; Costill, 1985; Devlin \& Williams, 1991). However, perhaps more important is the carbohydrate intake in relation to body weight, which was very high in the Kalenjin subjects. The average intake of $8.7 \mathrm{~g} / \mathrm{kg}$ body weight per $\mathrm{d}$ is well above the value of $6-7 \mathrm{~g}$ carbohydrate $/ \mathrm{kg}$ body weight per $\mathrm{d}$ thought necessary for replenishment of muscle glycogen after an hour's daily training at $75 \% \mathrm{VO}_{2 \max }$ (Pascoe et al. 1990). Even though there was a shorter exercise duration in the present study, the intensity was probably higher than $75 \% \mathrm{VO}_{2 \max }$ (Saltin et al. 1995), which elicits glycogen depletion to the same extent as exercise of longer duration and lower intensity.

Another factor that suggests an adequate replenishment of muscle glycogen among the Kalenjin subjects is the fact that they consumed a main meal immediately after finishing both of their daily training sessions. This indicates very good conditions for muscle glycogen replenishment as there is a higher rate of muscle glycogen resynthesis immediately after exercise compared with several hours after exercise (Price et al. 1994).

The total dietary fibre content $(45 \mathrm{~g}$ or $2.9 \mathrm{~g} / \mathrm{MJ})$ of the daily food intake of the adolescent Kalenjin runners was above the RDA of the Nordic countries $(25-35 \mathrm{~g})$ in absolute values but met the RDA ( $3 \mathrm{~g} / \mathrm{MJ})$ for the relative values (Sandström et al. 1996). Furthermore, we have not been able to determine the distribution between soluble and insoluble dietary fibre content. Therefore, we assume that the dietary fibre content in the food intake of the Kalenjin subjects most probably did not compromise carbohydrate uptake and absorption to any significant extent.

The diet of the Kalenjin runners came mainly from vegetable sources and consisted of a small range of food items, which seems to be common among endurance athletes in low-income countries (Cerqueira et al. 1979; Mukeshi \& Thairu, 1993). The small amount of meat consumed on a weekly basis was due to the relatively high value of cattle and other domestic animals among the Kalenjin. 
Even though the diet of the Kalenjin runners was mainly vegetarian, there was no sign of malnourishment at macronutrient level.

The diet of the Kalenjin runners was strikingly similar to the food intakes of the Mexican Tarahumaras, an indigenous people living approximately $2000 \mathrm{~m}$ above sea level and well-known for their exceptional endurance capacity in distance running (Cerqueira et al. 1979). In both groups the staple food items were maize and beans and intake of meat was very modest. Approximately $90 \%$ of the food intake came from vegetable sources in both groups. The similarity in diet intakes was also reflected in the distribution of the energy intake: carbohydrate 71 and $78 \%$; fat 15 and $9 \%$; as well as protein 15 and $13 \%$ for the Kalenjins and Tarahumaras, respectively.

When the dietary intakes of the Kalenjin subjects and distance runners of industrialized countries are compared, marked differences can be observed. The average intake of carbohydrates among elite distance runners in Australia, the United States and the Netherlands as a percentage of daily intake were 52, 49, and 50, respectively (Grandjean, 1989; van Erp-Baart et al. 1989; Burke et al. 1991), compared with $71 \%$ among the Kalenjin runners. The average fat consumption was $32 \%$ for the Australian and $34 \%$ for both the American and Dutch runners compared with only $15 \%$ for the Kalenjin subjects. The same differences in carbohydrate and fat intakes as compared with the Kalenjin runners can be found among distance runners who live in South Africa (Peters \& Goetzsche, 1997). The reason for the considerable differences in carbohydrate and fat intakes among the Kalenjin runners and runners from industrialized countries likely to be found in the availability of food items. Where the runners from the industrialized countries and South Africa have a great variety of food items to choose between, the Kalenjin runners have only a small selection of food items available to them.

The question remains whether the macronutrient dietary profile of the adolescent Kalenjin runners can explain, at least to some extent, their excellent athletic performances. There is no evidence to support the notion that the intake of macronutrients per se can explain the outstanding performances of the Kalenjin runners. Their dietary intake does live up to recommendations for endurance athletes except for some of the essential amino acid intakes, and the deficit of the latter could be a limiting factor when it comes to performance; consequently there may be room for improvement. However, it is also possible that a physiological adaptation to low essential amino acid intakes has taken place, in which a high protein turnover has resulted in an enhanced re-utilization of essential amino acids.

In conclusion, the total protein intake was well above the values recommended for endurance athletes, and essential amino acid intake was regarded as being in the borderline-to-low category. Furthermore, the high carbohydrate intake of the Kalenjin subjects was above the amount thought necessary for replenishment of muscle glycogen. Thus, a diet primarily based on vegetable sources and a small range of food items showed the ability to provide sufficient macronutrient intake for endurance athletes maybe with the exception of some essential amino acids.

\section{Acknowledgements}

The authors would like to thank the subjects who participated in the study, the former headmasters Mr Sawe and Mr Chemweno, athletics coach Samson Kimobwa as well as the cooking staff, all from Marakwet Secondary School. Furthermore, we wish to thank Henrik Larsen, MSc of the August Krogh Institute, University of Copenhagen, for collecting additional food samples at Marakwet Secondary School for our study. This study was supported by a grant from Team Denmark Research Foundation.

\section{References}

Black AE, Coward WA, Cole TJ \& Prentice AM (1996) Human energy expenditure in affluent societies: an analysis of 574 doubly-labelled water measurements. European Journal of Clinical Nutrition 50, 72-92.

Burke LM, Gollan RA \& Read RSD (1991) Dietary intakes and food use of groups of elite Australian male athletes. International Journal of Sport Nutrition 1, 378-394.

Calles-Escandon J, Cunningham JJ, Snyder P, Jacob R, Huszar G, Loke J \& Felig P (1984) Influence of exercise on urea, creatinine, and 3-methylhistidine excretion in normal human subjects. American Journal of Physiology 246, E334-E338.

Cappon JC (1985) District Atlas Elgeyo Marakwet. Iten, Kenya: Ministry of Planning and National Development.

Cerqueira MT, Fry MM \& Connor WE (1979) The food and nutrient intakes of the Tarahumara indians of Mexico. American Journal of Clinical Nutrition 32, 905-915.

Costill DL (1985) Carbohydrate nutrition before, during, and after exercise. Federation Proceedings 44, 364-368.

Devlin J \& Williams C (1991) Consensus statement on foods, nutrition and sports performance. Journal of Sports Sciences 9, Suppl., iii.

Food and Agriculture Organization/World Health Organization/ United Nations University (1985) Energy and Protein Requirements. Report of a Joint Expert Consultation. Technical Report Series, no. 724. Geneva: WHO.

Forslund AH, El-Khoury AE, Olsson RM, Sjödin AM, Hambraeus L \& Young VR (1999) Effect of protein intake and physical activity on 24-h pattern and rate of macronutrient utilization. American Journal of Physiology 276, E964-E976.

Friedman JE \& Lemon PWR (1989) Effect of chronic endurance exercise on retention of dietary protein. International Journal of Sports Medicine 10, 118-123.

Gontzea I, Sutzescu P \& Dumitrache S (1974) The influence of muscular activity on the nitrogen balance and on the need of man for proteins. Nutrition Reports International 10, 35-43.

Government of Kenya (1980) Report of the Child Nutrition Survey 1978/79. Nairobi: Central Bureau of Statistics and Nairobi Ministry of Economic Planning and Development.

Grandjean AC (1989) Macronutrient intake of US athletes compared with the general population and recommendations made for athletes. American Journal of Clinical Nutrition 49, 1070-1076.

Henderson SA, Black AL \& Brooks GA (1985) Leucine turnover and oxidation in trained rats during exercise. American Journal of Physiology 249, 137E-144E.

Hood DA \& Terjung RL (1987) Effect of endurance training on leucine oxidation in perfused rat skeletal muscle. American Journal of Physiology 253, E648-E656.

Jones DB (1941) Factors for Converting Percentages of Nitrogen in Foods and Feeds into Percentages of Proteins. Circular no. 183. Washington, DC: United States Department of Agriculture. 
Kiens B, Essen-Gustavsson B, Gad P \& Lithell H (1987) Lipoprotein lipase activity and intramuscular triglyceride stores after long-term high-fat and high-carbohydrate diets in physically trained men. Clinical Physiology 7, 1-9.

Kipkorir B (1985) Kenya's People: People of the Rift Valley Kalenjin. Nairobi, Kenya: Evans Brothers Limited.

Koletzko B (1999) Response to and range of acceptable fat intakes in infants and children. European Journal of Clinical Nutrition 53, Suppl. 1, S78-S83.

Korte R \& Simmons WK (1972) The nutritional status of preschool children in Kenya. East African Medical Journal 49, 513-520.

Kulin HE, Bwibo N, Mutie D \& Santner SJ (1982) The effect of chronic childhood malnutrition on pubertal growth and development. American Journal of Clinical Nutrition 36, 527-536.

Lemon PWR, Dolny DG \& Yarasheski KE (1997) Moderate physical activity can increase dietary protein needs. Canadian Journal of Applied Physiology 22, 494-503.

Meridith CN, Zackin MJ, Frontera WR \& Evans WJ (1989) Dietary protein requirements and body protein metabolism in endurance-trained men. Journal of Applied Physiology 66, $2850-2856$.

Merrill AL \& Watt BK (editors) (1973) Energy Value of Foods Basis and Derivation. Agriculture Handbook no. 74. Washington, DC: United States Department of Agriculture.

Motil KJ, Matthews DE, Bier DM, Burke JF, Munro HN \& Young VR (1981) Whole-body leucine and lysine metabolism: response to dietary protein intake in young men. American Journal of Physiology 240, E712-E721.

Mukeshi M \& Thairu K (1993) Nutrition and body build: a Kenyan review. World Review of Nutrition and Dietetics $\mathbf{7 2}$, 218-226.

Munro HN (1951) Carbohydrate and fat as factors in protein utilization and metabolism. Physiological Reviews 31, 449-488.

Naibei WC (1989) The development of sports in Kenya. In Geschichte der Leibesübungen: Perspektiven des Weltsports, pp. 537-551 [H Ueberhorst, editor]. Berlin: Bartels \& Wernitz.

Ngare DK \& Muttunga JN (1999) Prevalence of malnutrition in Kenya. East African Medical Journal 76, 376-380.

Pascoe D, Costill DL, Robergs R, Davis JA, Fink WJ \& Pearson D (1990) Effects of exercise mode on muscle glycogen restorage during repeated days of exercise. Medicine and Science in Sports and Exercise 22, 593-598.

Peters EM \& Goetzsche JM (1997) Dietary practices of South African ultradistance runners. International Journal of Sports Nutrition 7, 80-103.

Price TB, Rothman DL, Taylor R, Avison MJ, Shulman GI \& Shulman RG (1994) Human muscle glycogen resynthesis after exercise: insulin-dependent and -independent phases. Journal of Applied Physiology 76, 104-111.

Romijn JA, Coyle EF, Sidossis LS, Gastaldelli A, Horowitz JF, Endert E \& Wolfe RR (1993) Regulation of endogenous fat and carbohydrate metabolism in relation to exercise intensity and duration. American Journal of Physiology 265, E380-E391.

Saltin B, Larsen H, Terrados N, Bangsbo J, Bak T, Kim CK, Svendenhag J \& Rolf CJ (1995) Aerobic exercise capacity at sea level and at altitude in Kenyan boys, junior and senior runners compared with Scandinavian runners. Scandinavian Journal of Medicine and Science in Sports 5, 209-221.

Sandström B, Aro A, Becker W, Lyhne N, Pedersen JI \& Pórsdottir I (editors) (1996) Nordiska Näringsrekommendationer (28), Copenhagen: Nordiska Ministerrådet.

Sherman WM (1983) Carbohydrates, muscle glycogen and muscle glycogen supercompensation. In Ergogenic Aids in Sport, pp. 3-26 [MH Williams, editor]. Champaign, IL: Human Kinetics.

Sinclair D (1985) Human Growth After Birth. Oxford: Oxford Medical Publications.

Tarnopolsky MA, Macdougall JD \& Atkinson SA (1988) Influence of protein intake and training status on nitrogen balance and lean body mass. Journal of Applied Physiology 64, 187-193.

van Erp-Baart AMJ, Saris WHM, Binkhorst RA, Vos JA \& Elvers JW (1989) Nationwide survey on nutritional habits in elite athletes: Part I, carbohydrate, protein, and fat intake. International Journal of Sports Medicine 10, Suppl. 1, S3-S10.

van Steenbergen WM, Kusin JA, Nordbeck HJ \& Jansen AAJ (1984) Food consumption of different household members in Machakos, Kenya. Ecology of Food and Nutrition 14, 1-9.

Wadsworth GR (1960) The height, weight and blood pressure of healthy African men on a known dietary intake. East African Medical Journal 37, 709-714.

Walberg JL, Leidy MK, Sturgill DJ, Hinkle DE, Ritchey SJ \& Sebolt DR (1988) Macronutrient content of a hypoenergy diet affects nitrogen retention and muscle function in weight lifters. International Journal of Sports Medicine 9, 261-266.

West CE, Pepping F \& Temalilwa CR (editors) (1988) The Composition of Foods Commonly Eaten in East Africa. Wageningen, The Netherlands: Wageningen Agricultural University.

Wiehl DG (1942) Diets of a group of aircraft workers in Southern California. Milbank Memory Foundation Quarterly 20, 329-356.

Wolfe RR, Wolfe MH \& Shaw JHF (1984) Isotopic determination of amino acid/urea interactions in exercise in humans. Journal of Applied Physiology 56, 221-229. 